Document downloaded from:

http://hdl.handle.net/10251/81264

This paper must be cited as:

García Barreda, S.; Reyna Domenech, S. (2012). Below-ground ectomycorrhizal community in natural Tuber melanosporum truffle grounds and dynamics after canopy opening. Mycorrhiza. 22(5):361-369. doi:10.1007/s00572-011-0410-2.

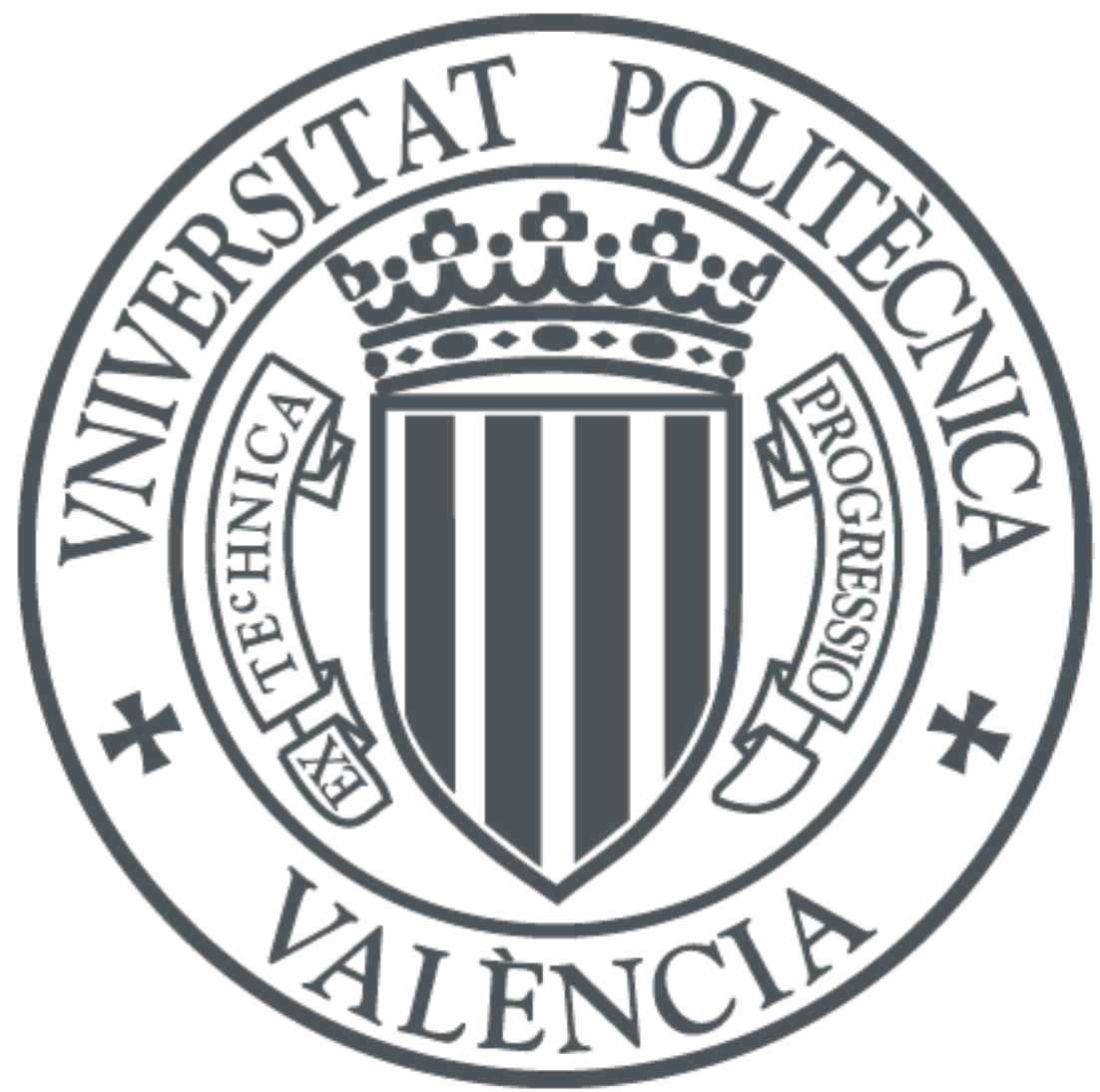

The final publication is available at

http://doi.org/ 10.1007/s00572-011-0410-2

Copyright Springer Verlag (Germany)

Additional Information 
This is the authors' accepted version of the article:

Garcia-Barreda S, Reyna S, 2012. Below-ground ectomycorrhizal community in natural Tuber melanosporum truffle grounds and dynamics after canopy opening. Mycorrhiza 22: 361-369.

The final publication is available at:

http://link.springer.com/article/10.1007/s00572-011-0410-2 


\title{
Below-ground ectomycorrhizal community in natural Tuber melanosporum truffle grounds and dynamics after canopy opening
}

\author{
$\underline{\text { Sergi Garcia-Barreda }}^{1}, \underline{\text { Santiago Reyna }}^{1,2}$ \\ ${ }^{1}$ Fundación Centro de Estudios Ambientales del Mediterráneo (CEAM). C/ Charles Darwin 14 Parque \\ Tecnológico. 46980 Paterna, Spain \\ ${ }^{2}$ ETS Ingeniería Agronómica y del Medio Natural. Universidad Politécnica de Valencia. Camino de Vera s/n. \\ 46021 Valencia, Spain
}

\begin{abstract}
The ectomycorrhizal fungus Tuber melanosporum fruits in association with Quercus in natural forests of Spain. Some of these stands are managed to keep an open canopy and meet the habitat requirements of the fungus. However, there are few quantitative studies analysing in these forests the relationship between soil environment and T. melanosporum. Eight forest stands which produce T. melanosporum have been monitored for six years in order to characterise the below-ground ectomycorrhizal community and to assess its temporal dynamics after experimental canopy opening. The brûlé, the ground where T. melanosporum fruits, shows a distinct ectomycorrhizal community, characterised by lower density of active ectomycorrhizal tips, lower morphotype richness per soil volume, higher abundance of T. melanosporum and lower abundance of Cenococcum geophilum than soil closest to the trunk of the host $Q$. ilex. Opening the canopy has not stimulated an increase in T. melanosporum, suggesting that a shift in the soil environment alone will not trigger the formation of new truffières in the short term. The dry climate of these truffières may be a factor, as T. melanosporum abundance appears to be sensitive to annual weather conditions.
\end{abstract}

Keywords Tuber melanosporum, Quercus ilex, ectomycorrhiza, brûlé, wild truffière, silviculture

\section{Introduction}

The European black truffle (Tuber melanosporum Vitt.) is an ectomycorrhizal (EM) fungus extensively cultivated due to its gastronomic value. The ground where it fruits, the so-called brûlé, is characterised by a scarce plant cover, due to the phytotoxic activity of the fungus (Splivallo 2008). In the wild, T. melanosporum frequently fruits in association with several Quercus species in the framework of forest dynamics. Such dynamics is not completely understood yet, but it is widely accepted that it implies the evolution of the root system of the truffle tree (i. e. the host tree), the physical environment of the soil, soil organic matter and composition of the EM community (Ricard et al. 2003; Sourzat et al. 2004). The occurrence of T. melanosporum ectomycorrhizas in wild brûlés and in nonproductive grounds remains little explored (Mello et al. 2006), as well as the influence of the environment on the belowground EM community of these soils (Hall et al. 2003). Such information would help to clarify the ecological role of T. melanosporum and would be useful for the management of the forest stands where T. melanosporum fruits (i. e. wild truffières). 
Koide et al. (2011) propose that EM communities are structured first by a host plant filter, then by an abiotic filter, followed lastly by competitive interactions. In this regard, $T$. melanosporum appears to thrive best in an early-seral environment of open forests, and fruiting has been found to decline as the forest canopy closes (Olivier et al. 2002; Reyna et al. 2004). To prevent this decline, canopy opening around the brûlé is widely recommended (Gregori et al. 2001; Sourzat et al. 2004) to maintain the appropriate abiotic conditions and minimize competitive displacement by other EM fungi. However, the effects of these cuttings on the below-ground EM community remain largely unexplored, and the abundance of fruiting bodies is considered to poorly reflect the composition of the below-ground EM community (Gardes and Bruns 1996). It is known that clearcutting alters the abundance of roots and changes the soil environment, affecting the EM community of the regenerating forest stand (Parsons et al. 1994; Jones et al. 2003a) even in the advance regeneration (Hagerman et al. 2001). On the other hand, in the patches of retention trees the EM community does not seem to change in the short term (Jones et al. 2008).

In this study we aim to characterise the below-ground EM community of wild truffières that have undergone a canopy opening treatment, and particularly to assess the occurrence of $T$. melanosporum ectomycorrhizas. We hypothesised that in the various environmental conditions of the truffière, the density and richness of the EM community would differ, as well as the occurrence of T. melanosporum ectomycorrhizas. A secondary aim of our study is to assess the effect of the canopy opening on the below-ground EM community. We hypothesised that the root gap created by the cutting would provoke (1) an increase in the density of root tips of the trees remaining and (2) a shift in the occurrence of the various EM species. Our study is part of a larger research effort trying to assess the feasibility of sustaining truffle yield of forests through silviculture.

\section{Material and methods}

Study site

The study was conducted in El Toro, Valencian Community, eastern Spain (39 $59^{\prime}$ to $40^{\circ} 2^{\prime}$ $\mathrm{N}, 0^{\circ} 44^{\prime}$ to $0^{\circ} 47^{\prime} \mathrm{W}, 990-1050 \mathrm{~m}$ a.s.1.). The climate is Continental Mediterranean, with a mean annual rainfall of $500-550 \mathrm{~mm}$ and a mean annual temperature of $11.9-12.4^{\circ} \mathrm{C}$. The soils are calcixerept developed on a quaternary calcareous glacis with little slope (less than 5\%), sandy clay loam texture, $\mathrm{pH}$ ranging from 7.7 to 8.3 and 2-3\% organic matter.

Before 1958, Quercus ilex L-Quercus faginea Lam. coppices and cereal cultures dominated the landscape. In the latter, Quercus were also present in field boundaries. About 1955, the 
local population began to harvest the truffles, most of which associated with $Q$. ilex. From 1958 to 1969, the site was reforested with Pinus nigra Arnold. By the 1990s, the reforestation had formed a close canopy (density: 900-2500 trees ha ${ }^{-1}$, canopy cover: 60-95\%) and the fruiting body production had sharply decreased. The Quercus survived as supressed trees under the pine overstorey, and a seedling bank of $Q$. ilex- $Q$. faginea spontaneously established under the pine reforestation. Over all these years, T. melanosporum had been intensively exploited as a common-pool resource and no management practices had been carried out.

In 2000-2001, silvicultural treatments were executed with the aim of opening the canopy and improving the habitat for $T$. melanosporum fruiting. Circular clearcuts were created around the brûlés, with radius depending on the height of the tree layer and ranging 14-50 m. Pines were systematically cut down, since they do not encourage T. melanosporum fruiting, all shrubs were removed, and Quercus were preserved and slightly pruned (less than $10 \%$ of the live crown was removed) (Reyna et al, 2004). A canopy cover less than 50\% was obtained within a radius of $15 \mathrm{~m}$ from the brûlé, whereas in the surrounding clearcut canopy cover was less than $30 \%$.

\section{Experimental design}

We have selected eight truffières with $Q$. ilex as the truffle tree. The truffières produce fruiting bodies of T. melanosporum, but not of other species of Tuber. Four of them had been treated in 2000 (January-April) and four in 2001 (January-April). In each truffière, we have sampled soil cores along two transects that orient north to south and run from the trunk of the truffle tree (the center of the plot) through the brûlé to the untreated pine stand. Four positions have been sampled within each transect: (1) near the trunk of the truffle tree (NTTT), (2) the centre of the brûlé, (3) the centre of the clearcut gap surrounding the brûlé and (4) the control pine stand. In each position, the roots of a $Q$. ilex have been sampled. The roots sampled both in the brûlé and NTTT correspond to the truffle tree, but crown shading, distance to the trunk and leaf litter accumulation differ (Table 1). The differences between these positions are clearly depicted in truffle plantations: when the tree is young, the brûlé typically appears closely around the trunk, but as the tree grows it moves away. In the context of this dynamics, the clearcut gap constitutes a potential space for the spread of the brûlé and for the formation of new truffières (Sourzat et al. 2004). In the clearcut gap, the most frequent EM trees that remained after the cutting are the juvenile (height $\leq 1.3 \mathrm{~m}$ ) $Q$. ilex that previously formed a 
seedling bank under the pine stand. In the control pine stand, where isolated adult $Q$. ilex and a $Q$. ilex seedling bank coexist, both adult and juvenile trees have been sampled (Table 1).

\section{Ectomycorrhizal root sampling}

From 2001 to 2006, the truffières have been annually sampled in late spring (May-June), since it is an optimum moment for the observation of $T$. melanosporum ectomycorrhizas (Bonet et al. 2001). In the brûlé, either a stone layer or a physical crust $(1-3 \mathrm{~cm})$ covers the soil. No fine roots grow either in the crust or in the leaf litter that accumulates on NTTT and the pine stand, so these layers have been discarded before taking the soil cores. The cores are cylindrical, with $100 \mathrm{ml}$ of volume and $10 \mathrm{~cm}$ of depth.

The samples have been gently washed with water and stored at $4^{\circ} \mathrm{C}$ for a maximum of 7 days. With the aid of binocular and optical microscopes, the active and the senescent fine root tips have been counted. Senescent tips are typically darkly coloured, with a wrinkled surface. The active tips have been classified as mycorrhized (turgescent live tips, covered by fungal mantles) or nonmycorrhizal. The latter have not been statistically analysed because they appear in only $8 \%$ of the samples. The ectomycorrhizas have been sorted in morphotypes according to the methodoly of Agerer (1987-2002) and with the aid of the descriptions in De Román (2003).

The below-ground EM community has been characterised through the density of active ectomycorrhizas, the morphotype richness (per $100 \mathrm{ml}$-core sample), the morphotype diversity (Shannon index), and the frequency of appearance (per sample) for the most common morphotypes. The occurrence of the most frequent species, Cenococcum geophilum Fr. and T. melanosporum, has been examined through its relative abundance (percentage of the total number of active EM tips).

\section{Statistics}

The aforementioned traits have been analysed through conventional and generalised linear mixed models (LMM) that include the position within the truffière and the orientation of the transect as fixed predictor variables, and the truffière as a random block variable $(\mathrm{n}=376)$.

Time from the canopy opening is treated as a repeated-measures variable: a linear and a quadratic component have been included. The width of $P$. nigra latewood (calculated as the mean for 20 trees in the study site) is included as a proxy for the annual weather conditions. The latewood section has been chosen instead of the earlywood or the total ring because it shows a better correlation with the conditions of the current year (Martín-Benito et al. 2008). 
Since the density of active root tips significantly differs among positions, this variable is included as a covariate in the LMMs that analyse the morphotype richness and frequency.

In the LMMs that analyse the occurrence of T. melanosporum, the number of digs made for harvesting T. melanosporum fruiting bodies (annual mean from 2001 to 2006) is included as a proxy for the fruiting body productivity of each truffière. Harvesters are guided by trained dogs to the ripe sporocarps, which are dug out with a small spade. In a previous study in the area, it was found that the annual number of digs in 10 truffières during four different fruiting seasons showed a significant and positive correlation with the annual weight of truffles harvested (Pearson's $\mathrm{r}=0.83, \mathrm{P}=0.003$ ).

In each LMM analysis, the covariance structure has been chosen following the restricted loglikelihood criterion. In order to avoid overparameterised models, LMM have been simplified by means of the log-likelihood criterion. The response variable is transformed when the model assumption are violated. Significant differences among treatments have been identified with an LSD test with Bonferroni correction.

\section{Results}

Density and diversity of the ectomycorrhizal community

According to the LMM, the density of active EM tips shows a significant relation with the position $(\mathrm{P}<0.001$; Table 2$)$ and the quadratic component of time $(\mathrm{P}<0.001)$, which reflects an initially negative trend, followed by a recovery from the fourth year (Fig. 1a). The density of active EM tips also shows a positive relation with the latewood width of the year $(\mathrm{P}<0.001)$ and significant differences among truffières $(\mathrm{P}=0.018)$. To assess the effect of the size of the sampled $Q$. ilex, an additional LMM has been performed solely on the data of the pine stand. Tree height has been added as a covariate, and it shows a positive and significant relation with the density of active EM tips $(\mathrm{P}=0.036)$.

According to the LMM, morphotype richness shows a significant relation with the interaction between position and density of active root tips $(\mathrm{P}<0.001)$. The slope of the simple regression between density of active root tips and morphotype richness is positive and significant in the four positions studied, but it is significantly higher in the brûlé (0.74) than in the rest (NTTT: 0.40, gap: 0.50, pine stand: 0.48). After removing the effect of the density of active root tips, morphotype richness shows a significant relation with the quadratic component of time $(\mathrm{P}<0.001)$, reflecting a continued decrease that becomes more pronounced with time. To assess the effect of the size of the sampled $Q$. ilex, an additional LMM has been performed 
solely on the data of the pine stand. Tree height has been added as a covariate, and it shows a positive and significant relation with morphotype richness $(\mathrm{P}=0.016)$.

The interaction between position and time shows a significant effect on Shannon index $(\mathrm{P}<0.001)$. The time trend is significantly more negative in the brûlé (simple slope: -0.04) than in the other positions (simple slopes for NTTT: 0.10, the gap: 0.05, and the pine stand: 0.09; Fig. 1c). Shannon index also shows a negative and significant relation with the latewood width of the previous year $(\mathrm{P}<0.001)$.

\section{Community composition}

In all, T. melanosporum has appeared in $33 \%$ of the samples, being the most frequent species in the brûlé. According to the LMM, its frequency of appearance shows a positive and significant relation with the density of active root tips $(\mathrm{P}<0.001)$ and the number of digs made to harvest $T$. melanosporum fruiting bodies in the truffière $(\mathrm{P}=0.025)$, as well as a significant relation with the position $(\mathrm{P}<0.001$; Table 2$)$. The orientation of the transect shows a significant effect on the frequency of T. melanosporum ectomycorrhizas $(\mathrm{P}=0.023)$, which is higher to the south.

The relative abundance of $T$. melanosporum ectomycorrhizas has been analysed solely in the brûlé and NTTT due to its low frequency in the remaining positions. It shows a significant relation with the interaction between position and the abundance of harvesting digs $(\mathrm{P}=0.002)$, and a significant relation with the interaction between position and latewood width of the previous year $(\mathrm{P}=0.001$; Fig. 2). Neither the relative abundance nor the frequency of appearance show a significant relation with the linear or the quadratic components of time (Fig. 1d).

C. geophilum is the most frequent morphotype overall (Table 3). The relative abundance of its ectomycorrhizas shows a significant relation with the position $(\mathrm{P}<0.001$; Table 2$)$ and a negative relation with the linear component of time $(\mathrm{P}<0.001)$.

Apart from these two species, 23 morphotypes have been detected, 10 of which appear in more than $5 \%$ of the samples (Table 3). The frequencies of the most common types show a positive and significant relation with the density of active root tips (types Genea: $\mathrm{P}=0.003$, Thelephoroid: $\mathrm{P}<0.001$, Scleroderma: $\mathrm{P}<0.001$, Hebeloma-Cortinarius: $\mathrm{P}<0.001$, Sebacina: $\mathrm{P}=0.004$, Russula: $\mathrm{P}<0.001$, Tuber brumale Vitt.: $\mathrm{P}<0.001$ and Tomentella galzinii Bourdot: $\mathrm{P}=0.023$ ). After removing the effect of this variable, a significant effect of the position has been found only for the types Scleroderma $(\mathrm{P}=0.007$; significantly more frequent in the brûlé than in NTTT), Hebeloma-Cortinarius ( $\mathrm{P}=0.009$; significantly more frequent in NTTT and 
the pine stand than in the brûle and the gap), Sebacina ( $\mathrm{P}=0.025$; significantly more frequent in the gap and the pine stand than in the brûlé), the type Unidentified-1 $(\mathrm{P}=0.009$; significantly more frequent in NTTT than in the pine stand), and T. brumale $(\mathrm{P}=0.011$; significantly more frequent in the brûle than in the rest). Among the various morphotypes, three distinct time trends have been found: (1) a significant quadratic trend, always reflecting an initially negative trend followed by a recovery from the third or the fourth year (types Genea: $\mathrm{P}<0.001$, Thelephoroid: $\mathrm{P}<0.001$, Unidentified-1: $\mathrm{P}<0.001$ and T. galzinii: $\mathrm{P}=0.040$ ); (2) a positive and significant linear trend (types Hebeloma-Cortinarius: $\mathrm{P}=0.003$, Sebacina: $\mathrm{P}<0.001$ and Russula: $\mathrm{P}<0.001$ ); or (3) no significant time trend. Two morphotypes show a significant relation with the latewood width of the current year (types Thelephoroid: $\mathrm{P}=0.001$ and Scleroderma: $\mathrm{P}=0.003$ ) and three with that of the previous year (types Genea: $\mathrm{P}<0.001$, Thelephoroid: $\mathrm{P}=0.008$ and Pisolithus: $\mathrm{P}=0.030$ ).

\section{Discussion}

\section{EM community of the truffle tree}

Knowing the factors that affect the EM community is fundamental to the management of sporocarp production in forests. Our results show that the below-ground EM community in wild brûlés is distinct from that existing close to the trunk of the truffle tree. The lower density of active EM tips, the higher ratio between morphotype richness and density of active root tips, the lower abundance of $C$. geophilum, and the higher abundance of $T$. melanosporum appear as distinctive features of the brûlé. Besides, the time trend of EM diversity after the canopy opening is contrasting.

The lower density of active EM tips in the brûlé could be attributable to the distance to the trunk (Luoma et al. 2006), to the soil environment (Deschaseaux and Ponge 2001; Jones et al. 2003b) or to the higher phytotoxic activity of T. melanosporum, since this species induces alterations on root growth (Pargney et al. 2001; Sourzat et al. 2004). It is difficult to isolate the role of each factor as they usually covariate in the truffière.

The scarce abundance of $C$. geophilum, another distinctive feature of the brûlé, could be attributable to the distance to the trunk (Dickie and Reich 2005), to a founder effect (i. e. earlier colonization by $T$. melanosporum) or to the competition with $T$. melanosporum. $C$. geophilum is considered a generalist fungus with a wide host and habitat range, indicating stressful environments (Dickie and Reich 2005). However, in our study it is less abundant in the brûlé than in NTTT, where the soil environment is more similar to that characterising dense forests (Table 1) and the density of active EM tips is higher. 
The contrasting density of active EM tips supports the theory that the dynamics of truffières is closely linked to the evolution of the root system of the truffle tree and the evolution of the soil environment in the brûlé (Ricard et al. 2003; Sourzat et al. 2004). The development of a forest stand leads to reduced insolation of the soil surface, an abiotic effect, and an increase in fine root density (Claus and George 2005), likely a competitive effect with invading EM fungi. These trends depart from the characteristics of the EM community found in the brûlé, T. melanosporum preferred habitat. According to Ricard et al. (2003) and Sourzat et al. (2004), EM communities of truffle trees are highly structured, with T. melanosporum dominating in the brûlé, but preceded and followed by an entourage of other EM fungi. Lian et al. (2006) found a similar pattern in Tricholoma matsutake Sing. shiros. In our study, the pattern of occurrence of T. melanosporum ectomycorrhizas agrees with that idea, particularly in truffières with higher fruiting body production.

Our data reveal that the responsiveness of $T$. melanosporum ectomycorrhizas to annual weather is different in the brûle from that in NTTT, pointing that the functioning of the population of $T$. melanosporum ectomycorrhizas could be determined by the interaction of abiotic factors and competitive interactions.

In the brûlé, T. melanosporum ectomycorrhizas appear to be more related to latewood width of the previous year than to the current year. This could be due to: (a) propitious weather conditions favour fruiting and the germinated spores colonise fine roots and form new ectomycorrhizas; and (b) the main shift in the relative abundance of $T$. melanosporum ectomycorrhizas from year to year occurs in autumn, when they have one of their two seasonal peaks (Bonet et al. 2001), whereas the sampling has been performed in spring. The seasonal patterns of EM populations differ across species (Courty et al. 2008) and our results indicate that the influence of weather is morphotype-specific. This could also contribute to changing the relative abundance of $T$. melanosporum ectomycorrhizas from one season to another.

\section{Temporal evolution after the canopy opening}

Canopy opening increases the insolation into the brûlé, reduces leaf litter accumulation and kills pine roots. However, in our study site (with intensive exploitation but no cultural practices carried out) it has not triggered a positive dynamics of $T$. melanosporum ectomycorrhizas. Their abundance seems to be in a rather steady state, driven solely by weather fluctuations. 
However, the density and the richness of the EM community have been affected by the canopy opening. They both initially decrease, approximating the EM community to the distinguishing features of the brûlé. This decrease may be due to loss of EM inocula provoked by pine mortality, but this factor does not seem relevant since nonmycorrhized active tips are scarce throughout all the monitoring. This indirectly points to the effect of the soil environment on the EM fungi (Jones et al. 2003a) or on the fine roots. In a subtropical forest, Jones et al. (2003b) found that the fine roots of pine and those of understorey species replaced each other over a pine density gradient, but when the understorey was removed the pine root density was primarily driven by abiotic factors.

In our truffières, the density of active EM tips recovers from the fourth year, suggesting an acclimation period to the new environment after which the fine roots and the associated ectomycorrhizas tend to compensate for the root gap left by the death of pines.

On the other hand, the morphotype richness decreases monotonously throughout all the monitoring, although its positive relation with the active root tips density partially compensates for this decrease (Fig. 1b). The contrasting time trends of the various morphotypes indicate that the canopy opening has exerted a distinct effect on the EM fungi, although it is not possible to discriminate which is the responsible factor.

In the model of truffle cultivation proposed by Sourzat et al. (2004), the gaps between the brûlés are considered a potential space for T. melanosporum spread. In the clearcut gaps of our study, $Q$. ilex regeneration is subjected to a physical environment of the soil similar to that in the brûlé. The density of active EM tips and the morphotype richness are low, like in the brûlé, but that is likely due to the small size of the sampled trees. This is supported by the fact that in the pine stand, tree size shows a positive effect on the density of active EM tips and morphotype richness.

The occurrence of T. melanosporum ectomycorrhizas, however, is much lower and has not shown a significant increase after the canopy opening (Fig. 1d), suggesting that the shift in soil environment alone does not trigger for the formation of new truffières in the short term. The apparent absence of time dynamics might also be owed to an inadequate sampling intensity (Taylor 2002). In the study site, the silvicultural treatment was executed in 26 ha (with a mean density of 581 juvenile $Q$. ilex $\mathrm{ha}^{-1}$ ) and T. melanosporum fruiting bodies have been harvested in only four juvenile trees that were previously nonproductive (Garcia-Barreda and Reyna, unpublished data). The feasibility of triggering the formation of new truffières through canopy opening has not been scientifically evaluated yet. The empirical experiences 
in France show conflicting results, with the best results obtained for adult $Q$. ilex 10-20 years old (Sourzat et al. 2008).

In conclusion, we have proposed a clear picture of the below-ground EM community in wild truffières under Continental Mediterranean climate. The structure of this community has been evaluated in the context of truffle cultivation. Most truffling regions in France and Italy lie on more wet climates (Hall et al. 2007), where Q. ilex is likely to show higher colonising ability and the forest canopy closes faster (Lloret et al. 2004; Zavala 2004). In these regions, the EM community is likely to differ in the density of fine roots and the speed of the response after the silvicultural treatment.

On the other hand, in agricultural soils which are periodically tilled, the fine roots and the ectomycorrhizas distribute preferentially deeper in the soil (Barry-Etienne et al. 2008). Since the EM fungi differ in their preference for soil depth (Courty et al. 2008), the EM community is likely to differ from that in wild truffières. In addition, the abundance of T. melanosporum ectomycorrhizas in our study is lower than generally reported in truffle plantations (which are usually established with nursery-inoculated seedlings on agricultural soils), and the richness of soil-borne EM fungi is higher (Sánchez-Durán et al. 2009; Águeda et al., 2010). Further study in nonproductive trees is necessary to elucidate its potential role in the renovation of truffle production.

Acknowledgements We gratefully acknowledge the support of the Conselleria de Medi Ambient (Generalitat Valenciana) and VAERSA. Comments from anonymous reviewers and editorial suggestions from Randy Molina greatly helped in improving the manuscript. The Fundación CEAM is partly supported by Generalitat Valenciana, Fundación Bancaja, and the projects GRACCIE (Consolider -Ingenio 2010) and FEEDBACKS (Prometeo - Generalitat Valenciana).

\section{References}

Agerer R (1987-2002) Colour atlas of ectomycorrhizae 1st-12th del. Eihorn-Verlag, Berlin

Águeda B, Fernández-Toirán LM, De Miguel AM, Martínez-Peña F (2010) Ectomycorrhizal status of a mature productive black truffle plantation. For Syst 19:89-97

Barry-Etienne D, Ricard JM, Diente S, Moundy PJ, Chandioux O, Fiorese D, Jaillard B, Serre F, Jourdan C (2008) Distribution of Tuber melanosporum mycorrhizas on rootstocks of holm-oaks (Quercus ilex) in production. $3^{\circ}$ Congresso Internazionale di Spoleto sul Tartufo, Spoleto, Italy

Bonet JA, Fischer CR, Colinas C (2001) Evolución mensual en campo de las ectomicorrizas de Tuber melanosporum Vitt. inoculadas en plantas de Quercus ilex. In: Actas del III Congreso Forestal Español. Junta de Andalucía. Available in http://www.congresoforestal.es. Accessed 3 June 2011 
Claus A, George E (2005) Effect of stand age on fine-root biomass and biomass distribution in three European forest chronosequences. Can J For Res 35: 1617-1625 doi:10.1139/X05-079

Courty P-E, Franc A, Pierrat J-C, Garbaye J (2008) Temporal changes in the ectomycorrhizal community in two soil horizons of a temperate oak forest. Appl Environ Microbiol 74(8): 5792-5801 doi:10.1128/AEM.0159208

De Román M (2003) Las ectomicorrizas de Quercus ilex subsp. ballota y su dinámica post-incendio en una zona potencialmente trufera. Dissertation, Universidad de Navarra

Deschaseaux A, Ponge J-F (2001) Changes in the composition of humus profiles near the trunk base of an oak tree (Quercus petraea (Mattus.) Liebl). Eur J Soil Biol 37:9-16 doi: 10.1016/S1164-5563(01)01064-0

Dickie IA, Reich PB (2005) Ectomycorrhizal fungal communities at forest edges. J Ecol 93:244-255 doi:10.1111/j.1365-2745.2005.00977.x

Gardes M, Bruns TD (1996) Community structure of ectomycorrhizal fungi in a Pinus muricata forest: aboveand below-ground views. Can J Bot 74:1572-1583 doi: 10.1139/b96-190

Gregori G, Elisei S, Pasquini L, Sacchi A, Spezi D (2001) Rigenerazione di una vecchia tartufaia coltivata di Tuber melanosporum Vitt. In: Courvoisier M, Olivier JM, Chevalier G (eds) Actes du V Congrès International Science et Culture de la Truffe. Fédération Française des Trufficulteurs, Aix-en-Provence, France, pp. 400-405

Hagerman SM, Sakakibara SM, Durall DM (2001) The potential for woody undestory plants to provide refuge for ectomycorrhizal inoculum at an interior Douglas-fir forest after clear-cut logging. Can J For Res 31:711721 doi:10.1139/cjfr-31-4-711

Hall IR, Yun W, Amicucci A (2003) Cultivation of edible ectomycorrhizal mushrooms. Trends Biotechnol 21:433-438 doi:10.1016/S0167-7799(03)00204-X

Hall IR, Brown GT, Zambonelli A (2007) Taming the truffle: the history, lore and science of the ultimate mushroom. Timber Press, Portland

Jones MD, Durall DM, Cairney JWG (2003a) Ectomycorrhizal fungal communities in young forest stands regenerating after clearcut logging. New Phytol 157:399-422 doi:10.1139/X09-072

Jones RH, Mitchell RJ, Stevens GN, Pecot SD (2003b) Controls of fine root dynamics across a gradient of gap sizes in a pine woodland. Oecologia 134:132-143 doi:10.1007/s00442-002-1098-y

Jones MD, Twieg BD, Durall DM, Berch SM (2008) Location relative to a retention patch affects the ECM fungal community more than patch size in the first season after timber harvesting on Vancouver Island, British Columbia. For Eco Manag 255:1342-1352 doi:10.1016/j.foreco.2007.10.042

Koide RT, Fernandez C, Petprakob K (2011) General principles in the community ecology of ectomycorrhizal fungi. Ann For Sci68:45-55 doi:10.1007/s1395-010-0006-6

Lian C, Narimatsu M, Nara K, Hogetsu T (2006) Tricholoma matsutake in a natural Pinus densiflora forest: correspondence between above- and below-ground genets, in association with multiple host trees and alteration of existing ectomycorrhizal communities. New Phytol 171:825-836 doi:10.1111/j.14698137.2006.01801.x

Lloret F, Peñuelas J, Ogaya R (2004) Establishment of co-existing Mediterranean tree species under a varying soil moisture regime. J Veg Sci 15:237-244 doi:10.1111/j.1654-1103.2004.tb02258.x 
Luoma DL, Stockdale CA, Molina R, Eberhart JL (2006) The spatial influence of Pseudotsuga menziesii retention trees on ectomycorrhiza diversity. Can J For Res 36:2561-2573 doi:10.1139/X06-143

Martín-Benito D, Cherubini P, Del Río M, Cañellas I (2008) Growth response to climate and drought in Pinus nigra Arn. trees of different crown classes. Trees 22:363-373 doi:10.1007/s00468-007-0191-6

Mello A, Murat C, Bonfante P (2006) Truffles: much more than a prized and local fungal delicacy. FEMS Microbiol Lett 260:1-8 doi:10.1111/j.1574-6968.2006.00252.x

Olivier J-M, Savignac J-C, Sourzat P (2002) Truffe et trufficulture. Fanlac, Périgueux, France

Pargney JC, Chevalier G, Dupré C, Genet P, Jalade M (2001) Étude des stromas fongiques se développant sur les racines des plants mycorhizés par la truffe. In: Courvoisier M, Olivier JM, Chevalier G (eds) Actes du V Congrès International Science et Culture de la Truffe. Fédération Française des Trufficulteurs, Aix-enProvence, France, pp. 167-172

Parsons WFJ, Miller SL, Knight DH (1994) Root-gap dynamics in a lodgepole pine forest: ectomycorrhizal and nonmycorrhizal fine root activity after experimental gap formation. Can J For Res 24:1531-1538 doi: $10.1139 / \times 94-200$

Reyna S, Garcia S, Folch L, Pérez-Badia R, Galiana F, Rodríguez-Barreal JA, Domínguez-Núñez JA, Saiz de Omeñaca JA, Zazo J (2004) Selvicultura trufera en montes mediterráneos. In: Vallejo R, Alloza JA (eds) Avances en el estudio de la gestión del monte mediterránea. Fundación CEAM, Valencia, Spain, pp 523-546

Ricard JM, Bergougnoux F, Callot R, Chevalier G, Olivier JM, Pargney JC, Sourzat P (2003) La truffe Guide technique de trufficulture. Ctifl, Paris

Sánchez-Durán S, De Miguel AM, Palazón C, González Armada B, Sáez R, Barriuso J (2009) Estado de micorrización de árboles truferos en función de su carácter productivo y su edad. In: Actas del $5^{\circ}$ Congreso Forestal Español. Sociedad Española de Ciencias Forestales - Junta de Castilla y León. Available in http://www.congresoforestal.es. Accessed 3 June 2011

Sourzat P, Génola L, Chaumeil F, Chédozeau N (2004) Questions d'ecologie appliquées à la trufficulture. Lycée Professionnel Agricole de Cahors-Le Montat, Le Montat, France

Sourzat P, Bouyssieres D, Brunet-Ruamps E, Chaumeil F, Dubiau J-M, Michels C, Génola L, Saenz W, Sanchez A (2008) La rénovation des anciennes plantations et la sylviculture truffière. Fédération Française des Trufficulteurs, Le Montat, France

Splivallo R (2008) Biological Significance of Truffle Secondary Metabolites. In: Karlovsky P (ed) Secondary Metabolites in Soil Ecology. Soil Biology vol 14, Springer Berlin Heidelberg

Taylor AFS (2002) Fungal diversity in ectomycorrhizal communities: sampling effort and species detection. Plant Soil 244:19-28 doi:10.1023/A:1020279815472

Zavala, MA (2004) Estructura, dinámica y modelos de ensamblaje del bosque mediterráneo: entre la necesidad y la contingencia. In: Valladares F (ed) Ecología del bosque mediterráneo en un mundo cambiante. Ministerio de Medio Ambiente, Madrid, pp. 249-280 

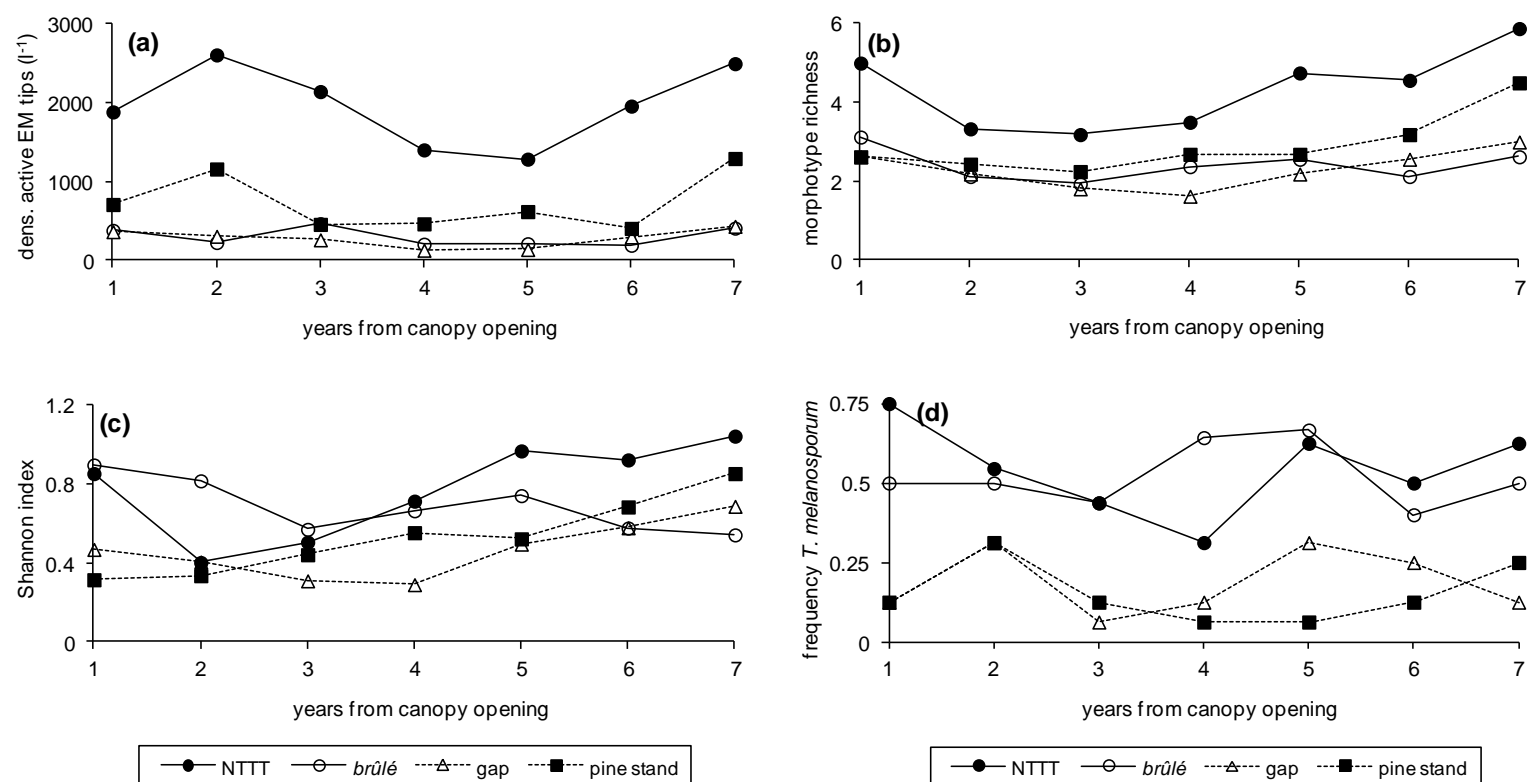

Fig. 1 Density of active EM tips (a), morphotype richness in the $100 \mathrm{ml}$-core samples (b), Shannon index (c), and frequency of appearance of $T$. melanosporum (d) across the spatial positions of the truffière after the canopy opening. Each point is the mean of 16 samples 


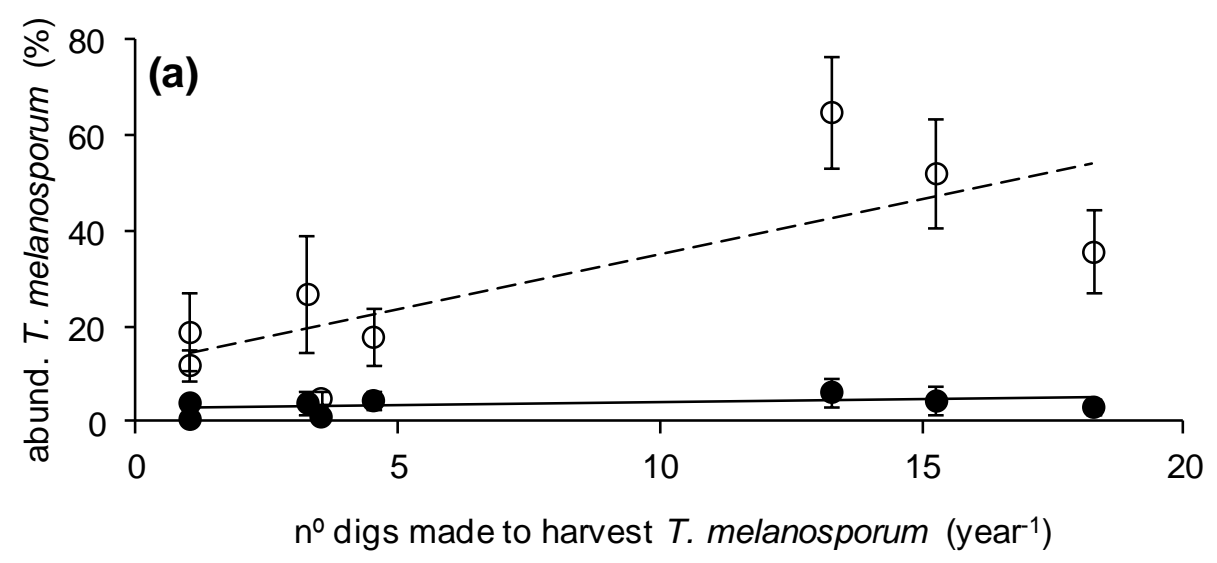

- NTTT O brûlé

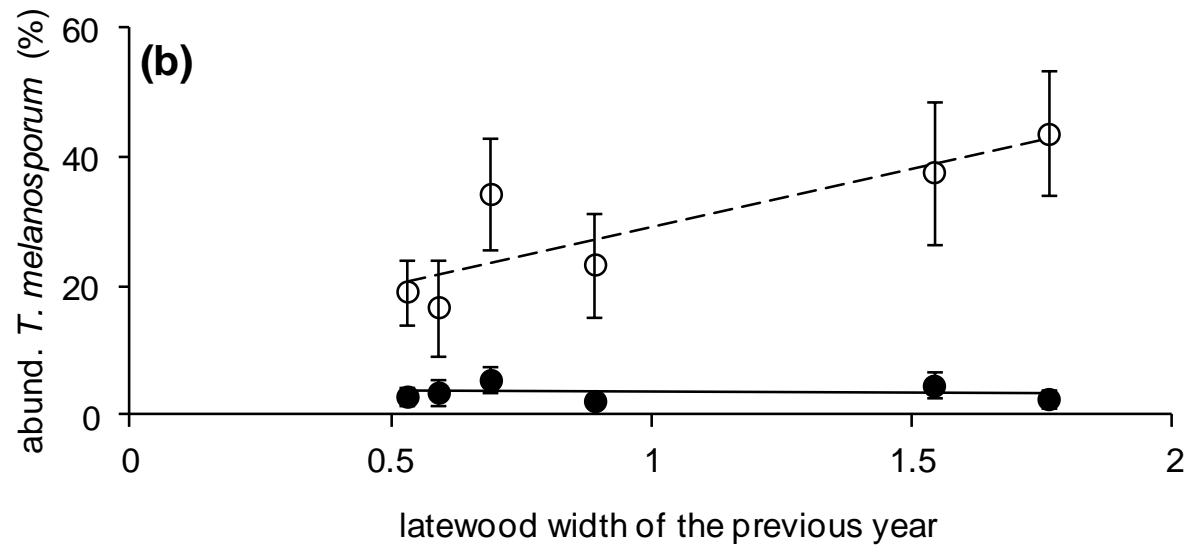

- NTTT O brûlé

Fig. 2 Mean for the relative abundance of T. melanosporum ectomycorrhizas in the brûlé and near the trunk of the truffle tree (NTTT), according to the number of digs made to harvest $T$. melanosporum fruiting bodies (annual mean from 2001 to 2006) (a) and the latewood width of the previous year. Lines are regression estimates of mean abundance. Latewood width is expressed as a ratio to the mean in the period 1997-2008. Bars indicate standard error 
Table 1 Environmental conditions in the four sampled spatial positions and characteristics of the sampled trees (NTTT: near the trunk of the truffle tree)

\begin{tabular}{|l|l|l|l|l|}
\hline $\begin{array}{l}\text { Direct insolation on } \\
\text { the soil surface }\end{array}$ & No & brûlé & clearcut gap & pine stand \\
\hline $\begin{array}{l}\text { Leaf litter } \\
\text { accumulation }\end{array}$ & Yes (Quercus) & No & No & No \\
\hline $\begin{array}{l}\text { Fruiting of } \\
\text { melanosporum }\end{array}$ & No or occasional & Yes & No & No \\
\hline Sampled tree species & Q. ilex & $Q$. ilex & $Q$. ilex & Q. ilex \\
\hline $\begin{array}{l}\text { Tree height in 2001 } \\
\text { (m) }\end{array}$ & $4-8$ & $4-8$ & $0.2-0.7$ & $\begin{array}{l}\text { Juveniles: } 0.1-1 \\
\text { Adults: } 2-7\end{array}$ \\
\hline $\begin{array}{l}\text { Distance from the } \\
\text { sampling point to the } \\
\text { tree (m) }\end{array}$ & $0.5-1.5$ & $4-7$ & $0.5 \times$ height & $\begin{array}{l}\text { Juveniles: } 0.5 \times \text { height } \\
\text { Adults: } 0.5-1.5\end{array}$ \\
\hline
\end{tabular}

Table 2 Mean characteristics of the below-ground EM community across the spatial positions of the truffière. Significant differences among levels $(\alpha=0.05)$ are shown with letters in each row. NTTT: near the trunk of the truffle tree

\begin{tabular}{|c|c|c|c|c|}
\hline & NTTT & brûlé & gap & pine stand \\
\hline $\begin{array}{l}\text { Density of active ectomycorrhizas } \\
\left(\text { litre }^{-1}\right)^{\mathrm{a}}\end{array}$ & $951 \mathrm{a}$ & $65 \mathrm{c}$ & $94 \mathrm{bc}$ & $220 \mathrm{~b}$ \\
\hline Morphotype richness ${ }^{b}$ & 2.8 & 2.9 & 2.5 & 2.4 \\
\hline Shannon index ${ }^{\mathrm{a}}$ & $0.75 \mathrm{a}$ & $0.66 \mathrm{ab}$ & $0.45 \mathrm{c}$ & $0.53 \mathrm{bc}$ \\
\hline Frequency of T. melanosporum ${ }^{\mathrm{b}}$ & $0.28 \mathrm{~b}$ & $0.62 \mathrm{a}$ & $0.24 \mathrm{bc}$ & $0.12 \mathrm{c}$ \\
\hline Abundance of T. melanosporum (\%) ${ }^{\mathrm{a}}$ & $3.8 \mathrm{~b}$ & $29.7 \mathrm{a}$ & - & - \\
\hline Abundance of C. geophilum $(\%)^{\mathrm{a}}$ & $68.2 \mathrm{a}$ & $22.3 \mathrm{~b}$ & $59.6 \mathrm{a}$ & $68.2 \mathrm{a}$ \\
\hline
\end{tabular}

${ }^{a}$ Predicted means at year 3 and width of latewood ring equal to the mean value from 2001 to 2006

${ }^{\mathrm{b}}$ Predicted means at year 3, density of active root tips in the $100 \mathrm{ml}$-sample $=265$ tips $^{-1}$ and width of latewood ring equal to the mean value from 2001 to 2006 
Table 3 Description and frequency of appearance of the 12 most common morphotypes. The morphotypes are ordered according to their global frequency in the sampling

\begin{tabular}{|c|c|c|c|c|}
\hline Morphotype & Freq. & Colour & Mantle $^{\mathrm{a}}$ & Emanating elements $^{\mathrm{b}}$ \\
\hline $\begin{array}{l}\text { Cenococcum } \\
\text { geophilum } \mathrm{Fr} .\end{array}$ & 0.77 & Black & PL-type G & $\begin{array}{l}\text { H: dark brown, thick-walled, non- } \\
\text { ramified, non-clamped }\end{array}$ \\
\hline $\begin{array}{l}\text { Tuber } \\
\text { melanosporum } \text { Vitt. }\end{array}$ & 0.33 & $\begin{array}{l}\text { Orange to } \\
\text { brown }\end{array}$ & PS-type M & $\begin{array}{l}\mathrm{C} \text { : yellowish-reddish, right angle- } \\
\text { ramified, non-clamped }\end{array}$ \\
\hline $\begin{array}{l}\text { Type Genea (De } \\
\text { Román 2003) }\end{array}$ & 0.24 & Redish brown & $\begin{array}{l}\text { PS-type } \\
\text { L/K }\end{array}$ & $\begin{array}{l}\text { C: yellowish-reddish, rigid, } \\
\text { ramified, enlarged base, non- } \\
\text { clamped }\end{array}$ \\
\hline Type Theleforoid & 0.23 & $\begin{array}{l}\text { Whitish grey } \\
\text { to brown }\end{array}$ & PL-type D & $\begin{array}{l}\text { C: hyaline, awl-shaped, non- } \\
\text { ramified, with clamped (when only } \\
\text { one) and non-clamped septa } \\
\text { H: hyaline, Y-shaped ramification, } \\
\text { anastomizing, with clamped and } \\
\text { non-clamped septa }\end{array}$ \\
\hline $\begin{array}{l}\text { Type Scleroderma } \\
\text { (De Román 2003) }\end{array}$ & 0.22 & Pale yellow & PS-type A & $\begin{array}{l}\text { H: hyaline-yellowish, ramified, } \\
\text { enlarged in the septa, non-clamped } \\
\text { R: type D, whitish-yellowish, with } \\
\text { knot-like structures in ramifications }\end{array}$ \\
\hline $\begin{array}{l}\text { Type Hebeloma- } \\
\text { Cortinarius } \quad \text { (De } \\
\text { Román 2003) }\end{array}$ & 0.19 & $\begin{array}{l}\text { Whitish rose } \\
\text { to brown }\end{array}$ & PL-type B & $\begin{array}{l}\text { H: hyaline, ramified, enlarged in } \\
\text { the septa, clamped, anastomizing } \\
\text { R: type A, hyaline, with fan-like } \\
\text { connection to the mantle }\end{array}$ \\
\hline $\begin{array}{l}\text { Type Sebacina (De } \\
\text { Román 2003) }\end{array}$ & 0.15 & $\begin{array}{l}\text { Pale yellow } \\
\text { to greyish- } \\
\text { brown }\end{array}$ & $\begin{array}{l}\text { PL-PS, } \\
\text { type } \mathrm{H}\end{array}$ & $\begin{array}{l}\mathrm{H} \text { : hyaline, thin, Y-shaped } \\
\text { ramification with enlarged walls, } \\
\text { scarce and non-clamped septa }\end{array}$ \\
\hline Unidentified-1 & 0.12 & $\begin{array}{l}\text { Pale yellow } \\
\text { to brown }\end{array}$ & PS-type P & $\begin{array}{l}\text { C: hyaline, short, non-ramified, } \\
\text { capitate, non-clamped } \\
\text { H: hyaline-yellow, sometimes with } \\
\text { ring-like shapes, ramified, non- } \\
\text { clamped }\end{array}$ \\
\hline $\begin{array}{l}\text { Type Russula (De } \\
\text { Román 2003) }\end{array}$ & 0.10 & $\begin{array}{l}\text { Witish to } \\
\text { yellowish } \\
\text { brown }\end{array}$ & PL-type B & C: hyaline, flask-shaped \\
\hline $\begin{array}{l}\text { Type Pisolithus (De } \\
\text { Román 2003) }\end{array}$ & 0.09 & $\begin{array}{l}\text { Golden- } \\
\text { orange }\end{array}$ & PL-type B & $\begin{array}{l}\text { H: yellowish brown, ramified, } \\
\text { sometimes ribbon-like, clamped } \\
\mathrm{R} \text { : type B, brown, ramified, with } \\
\text { inflated cells }\end{array}$ \\
\hline Tuber brumale Vitt. & 0.09 & $\begin{array}{l}\text { Orange } \\
\text { brown }\end{array}$ & PS-type M & $\begin{array}{l}\text { C: yellow, bristle-like, enlarged } \\
\text { base, usually without septa }\end{array}$ \\
\hline $\begin{array}{l}\text { Tomentella galzinii } \\
\text { Bourdot in Bourdot } \\
\text { and Galzin }\end{array}$ & 0.08 & $\begin{array}{l}\text { Yellowish to } \\
\text { greenish } \\
\text { brown }\end{array}$ & PS-type L & $\begin{array}{l}\text { C: bristle-like, enlarged base, } \\
\text { yellow below the first septa, } \\
\text { clamped } \\
\text { H: yellow, ramified, clamped } \\
\text { R: type A, yellowish-greenish }\end{array}$ \\
\hline
\end{tabular}

${ }^{a}$ PL: plectenchymatous, PS: pseudoparenchymatous, type according to Agerer (1987-2002)

${ }^{\mathrm{b}} \mathrm{C}$ : cystidia, H: hyphae, R: rhizomorph 